\title{
The practice of Cousin Marriage in the Community of Kalola Village, Pasangkayu Regency, West Sulawesi
}

\author{
Muhammd Rizal Soulisa ${ }^{1}$, Lukman S. Thahir ${ }^{2}$, Malkan Malkan ${ }^{3}$ \\ ${ }^{1}$ Islamic Law Department, Postgraduate, Institut Agama Islam Negeri Palu \\ ${ }_{2}^{2}$ Islamic Law Department, Postgraduate, Institut Agama Islam Negeri Palu \\ ${ }^{3}$ Faculty of Islamic Economis and Business, Institut Agama Islam Negeri Palu
}

\begin{abstract}
The aim of this paper is to discuss the practice of cousin marriage in the community of Kalola Village, Pasangkayu Regency, West Sulawesi. This study uses qualitative methods and data was gathered through observation, in-depth interviews, and written material. Data analysis was analyzed using grounded theory approach. the background of a cousin marriage in the Mandar tribe community in Kalola Village is a tradition that has been strong for a long time in the community, in addition to the factor of maintaining a large family and protecting property. Meanwhile, the impact of cousin marriage includes both positive and negative impacts. The positive impact is to reduce the number of conflicts in the community and strengthen local political systems, while the negative impact is the breakdown of kinship in the event of conflict and divorce and health risks.
\end{abstract}

ARTICLE

INFORMATION

\author{
Keywords: \\ Causin marriage, \\ sociology, \\ anthropology, Kalola \\ village
}




\section{Introduction}

Cousin marriage is often referred to as endogamous marriage. In Kamus Besar Bahasa Indonesia, endogamy means the principle of marriage which requires people to find a mate in their social environment, for example in their family environment, neighborhood, and close family environment. ${ }^{1}$

Endogamous marriage is a form of marriage that applies in society that only allows community members to marry other members of their own group. Strictly speaking, this endogamous marriage is a marriage between relatives or cousins who are still one descendant either from the father's side (patrilineal) or the mother. Relatives may marry their female cousins because those closest to the main line are seen as bearers of the kinship tradition and great attention is paid to genealogy. ${ }^{2}$ In another definition, it is stated that endogamous marriage is a system of marriage that requires marrying a spouse of the same clan (one tribe or descent) with him or prohibiting someone from marrying someone from another clan or tribe. ${ }^{3}$

Islam wisely gives directions in choosing a wife. In a history, Ibn Umar once ordered to marry a woman from a

\footnotetext{
${ }^{1}$ Badan Pengembangan dan Pembinaan Bahasa Kementrian Pendidikan dan Kebudayaan, Kamus Besar Bahasa Indonesia, (Jakarta, 2018), 105.

2Syarifah Ema Rahmaniah, "Multikulturalisme Dan Hegemoni Politik Pernikahan Endogami," Implikasi Dalam Dakwah Islam 2, no. Jurnal Penelitian Sosial Keagamaan (2014): 433-456.

${ }^{3}$ Ridwan Halim, Hukum Adat Dalam Tanya Jawab Cet I (Jakarta: Ghali Indonesia, 1987), 43.
}

distant relative in order to be stronger. ${ }^{4,5}$ The point is that marriage is not just a matter of worship or the fulfillment of biological needs, but it is also a means to unite two different family groups and to strengthen better social bonds. Thus, marrying distant relatives is preferable to close relatives, in this case cousins.

According to the people of Mandar Tribe living in Kalola Village, the ideal marriage occurs if a man and woman get a mate from within their family, both from the mother and father, because they are considered as successors who will raise the big name of the family.

Changes in the condition of society today are still trapped in thoughts that originate from the customs of the previous community which flow and develop and are firmly embedded in future generations which causes these habits to continue to exist and develop in accordance with the times. It can be explained that the development of Islamic law in Indonesia can be seen from the context of tug of war between revelation and reason, or tradition and modernity, ${ }^{6}$ where there are still many Muslims who carry out their daily activities with traditions or habits that

${ }^{4}$ Sulaiman Bin Admad Bin Yahya AlFaifi, Ringkasan Fikih Sunnah Cet I (Jakarta: Umul Qura, 2014), 43.

5 Rusli, R. (2018). Fikih Ekologi dan Kearifan Tradisional: Tinjauan Terhadap Konsep Ihya' al-Mawat dan Hima. Hunafa: Jurnal Studia Islamika, 5(3), 287-298.

6 Rusli Rusli, Nalar Fikih Tradisionalis Progresif: Analisis Terhadap Epistemologi Ibrahim Hosen, 1st ed. (Yogyakarta: Maghza Books, 2014), 3.

e-ISSN: 2715-4580 p-ISSN: 2715-8268 
come from traditional ways of thinking or in accordance with the customs and habits of the community in a place.

Selo Soemardjan defines changes in socio-cultural conditions as all changes in social institutions that affect their social system. The social system can be in the form of values, norms, and behavior patterns of social groups in the community. ${ }^{7}$ Gillin and Gillin said, cited in Soemardjan, 8 that socio-cultural change is a variation of the accepted way of life of society, either due to changes in geographical conditions, culture, demography, ideology, or because of new discoveries within the scope of community life. Meanwhile, Samuel Koenig, cited in Basrowi, ${ }^{9}$ defines sociocultural changes as modifications that occur in social life patterns caused by internal or external factors. Internal factors come from within humans. Meanwhile, external factors come from outside humans.

Looking at the explanation above, it can be understood that changes in community culture are changes in behavior patterns and socio-cultural elements that affect changes in social systems and structures from various fields, including marriage problems that occur in the Mandar Tribe people who live in Kalola Village, Bambalamotu District, Pasangkayu Regency. In this

7Muhammad Fadil, Sosiologi Pendidikan, ed. Cet I (Yogyakarta: UIN Malik Pres, 2010).

8Soerjono Soekanto, Sosiologi Suatu Pengantar, Cet I. (Jakarta: Rajawali Press, 1990), 335-336.

${ }^{9}$ Muhammad Basrowi, Memahami Sosiologi, Cet I. (Surabaya: Lutfansah Mediatama, 2004), 194. community, cousin marriage custom is found, which has become a community tradition to maintain and strengthen the lineage of their extended family.

This paper discusses cousin marriage in Kalola Village, Bambalamotu District, Pasangkayu Regency, from cultural anthropology analysis. Here, the author tries to describe the history, way of thinking and behavior of these people in the practice of cousin marriage which is an integral part of the local community culture. By analyzing cultural anthropology as well, the author can find out how the impact of cousin marriage, both in the form of positive and negative impacts.

\section{Literature Review}

\subsection{Cultural Perspective of Marriage}

Every social group knows a set of rules regarding marriage. There are provisions, for example, regarding whether the match must come from members of the group itself, or must it be from another group; who are among the group members those who may be married or not; the number of women who can be married at the same time; the place of residence after marriage; and the determination of lineage. It is all regulated in the rules that apply in a region, such as norms, customs or culture. Then the marriage process must be in accordance with the conditions of the community.

Basically, in community life there are two types of marriage, namely monogamy and polygamy. ${ }^{10}$ Other rules

${ }^{10}$ Ibid., 43.

e-ISSN: 2715-4580 p-ISSN: 2715-8268 
that apply in marital relations are exogamy and endogamy. Exogamy is a marriage system that prohibits marriage with group members, while endogamy is a system that requires marriage with group members. The obligation or recommendation to marry someone from a racial, religious, ethnic, caste or social class group is itself a form of endogamy rule, while the prohibition to marry someone from the same clan is a form of exogamy rules. ${ }^{11}$

Marriage is a medium for establishing a family. Family, sociologically, has functions. First, the the family regulates the distribution of biological impulses to humans in a legal and civilized manner. There is no society that allows free sex between anyone in society. Second, reproduction in the form of offspring development is always limited by the rules that place this activity in the family. Third, the family functions to socialize new members of society, so that they can act out what is expected of them, ${ }^{12}$ because family has a big role in shaping a person. Fourth, the family has an affective function, where the family gives love to a child. Studies have shown that a child who does not receive love can develop into a disorder, suffer mental disorders and can die. Fifth, the family provides protection to its members, both physical and psychological protection. ${ }^{13}$

${ }^{11}$ Ibid., 44.

12 See Rusli Rusli, "The Role of Family in Preventing Social Conflict in Society From Islamic Perspectives," HUNAFA: Jurnal Studia Islamika 17, no. 1 (2020): 108-122.

${ }^{13}$ Ibid., 66.

\subsection{Cousin Marriage}

One of the customs that is still practiced in the issue of marriage is cousin marriage. This is also known as endogamy marriage; that is, a marriage that is carried out between close families who are still bound in blood relatives with the aim of maintaining the strength of family. According to Hadikusuma, cousin marriage is a marriage system that requires marrying one offspring with him and prohibits the marriage with other people who are not of the same tribe or descent. Cousin marriage is one of the unlawful marriages. Therefore, the marriage may be carried out and it is considered valid by law.

In the anthropological analysis, the cousin marriage tradition includes two main forms: the patrilateral parallelcousin pattern and matrilateral cross-cousin pattern. The former is a pattern in which a man marries a woman from a father's brother, while the later is a marriage system in which a man marries the daughter of his mother's sister.

According to Koentjaraningrat, many people in the world have a preference for marrying cross-cousin. Meanwhile, parallel-cousin marriages usually dominate Muslim societies in the Middle East, West Asia and Central Africa. ${ }^{14}$

Much of the scientific literature on cousin marriage is concentrated on the effects of this kind of marriage on fertility and health. Many also find that in Pakistani society, cousin marriages can cause congenital diseases, such as heart

14Ibid., 66.

e-ISSN: 2715-4580 p-ISSN: 2715-8268 
disease, tala semia, and other disabilities in children. Post-neonatal mortality, childhood morbidity, and hemoglobinopathies are common in offspring of these marriages. Zaman found that among the children, whose parents were cousins, two were blind and one died, and one baby died after one month of birth. He began to realize that this was caused by a genetic problem in the cousin's marriage partner. ${ }^{15}$

Furthermore, from a sociological point of view, cousin marriages can weaken the relationship between husband and wife, which sometimes makes their relationship unsafe, especially if they initially lived in the same house.

However, marriage between cousins also has a good side; for example, it can strengthen and strengthen internal family ties and also minimize conflicts that come from within and outside.

\section{Methodology}

This study uses qualitative approach investigating the practice of cousin marriage in the community of Kalola Village, Pasangkayu Regency, and West Sulawesi. Data were collected through observation, in-depth interview with twenty citizens from the district and shared written documents. The interview last between 30 to 45 minutes.

Data analysis consists of several procedures: reduction and verification

${ }^{15}$ Muhammad Zaman "Marriage of cousins: Congenital diseases and people'sperceptions in Pakistan, a publichealth challenge." Public Healt Policy. Vol. 6 2010: 381-383. techniques with various data sources. ${ }^{16} 17$ The reduced data is then analyzed reflecting on theoretical concepts used in this study. ${ }^{18}$

\section{Result and Discussion}

\subsection{The Background of Cousin Marriage}

Based on the research results, there are several factors behind the occurrence of cousin marriages carried out by the people of Kalola Village.

1. Tradition or culture

One of the factors behind the marriage of cousins in Kalola Village, which is inhabited by the Mandar tribe, is a old tradition that is deeply rooted in this society. In the interview with Hasan Logawali, he said,

Cousin marriage is a marriage that we have been doing here for a long time (Kalola Village) because it has become a habit for us which has always been passed down by our parents; so, don't be surprised to see many have families here. ${ }^{19}$

${ }^{16}$ Nurdin, N. (2017a). Research in Online Space: The Use of Social Media for Research Setting Jurnal Sistem Informasi (Journal of Information System), 13(1), 67-77.

17 Nurdin, N. (2017b). To Research Online or Not to Research Online: Using Internet-Based Research in Islamic Studies Context. Indonesian Journal of Islam and Muslim Societies, 7(1), 31-54.

18 Nurdin, N., \& Yusuf, K. (2020). Knowledge management lifecycle in Islamic bank: the case of syariah banks in Indonesia. International Journal of Knowledge Management Studies, 11(1), 59-80. https://doi.org/10.1504/ijkms.2020.105073

19 Interview with Hasan Logawali, Kalola, 5 April 2020.

e-ISSN: $2715-4580$ p-ISSN: 2715-8268 
Hasan also added that no one knows specifically when the first time this cousin's marriage was held. This is because since the community entered Bambalamotu District, the tradition has been carried out until now.

2. Maintaining the integrity of the family

This cousin marriage was carried out on the grounds of maintaining the strength and integrity of the family so as not to be separated. In interview with Hajri Abdul Rasyid, he said,

The reason parents used to marry us fellow cousins so that the family was not scattered (not separated), all gathered in one family, and parents also would not marry their children except to cousins. ${ }^{20}$

The people of Kalola Village consider that cousin marriage is one of the most effective marriages to strengthen internal family ties, and can also easily resolve all conflicts that come from both inside and outside..$^{21}$ With the family relationship, the people of Kalola Village can find out the condition of each family, both far and near family.

Cousin marriage is an effective way of maintaining the internal integrity of the family so that it is not easily scattered. With a cousin marriage, the

\footnotetext{
20Interview with Hajri Abdul Rasyid, Kalola, 7 April 2020.

${ }^{21}$ Muslih, I., Nurdin, N., \& Marzuki, M. (2020). Effectiveness of Marriage Services Through Information System Management (SIMKAH) at Palu City Religious Court INTERNATIONAL JOURNAL OF CONTEMPORARY ISLAMIC LAW AND SOCIETY, 2(1), 20-36.
}

people of Kalola Village can easily gather families in one particular area, and can even create new communities that can exist along with the times.

\section{Protection of the properties}

Based on the interview with Hajri Abdul Rasyid in Kalola Village, it can be said that cousin marriage was deemed as one of the ways to protect family assets that were inherited by their parents first. These people think that being married to another person will mix ownership of property with people who are not from their family.

It is also said that old people would not marry off their children except to only their cousins. From this, it can be seen that the community closely holds their customs and culture in maintaining the strength and integrity of the family. However, along with the development of the times and science, some Kalola people began to rethink this principle "will not marry except only with cousins". This means that some of them begin to marry off their children to people who are far away, and some others still maintain this culture.

Those who have left this culture are those who live in urban areas, namely the city of Pasangkayu, while those who still practice this culture mostly reside in Kalola Village. Those who live in urban areas choose to marry people from outside West Sulawesi, such as Central Sulawesi, South Sulawesi, Southeast Sulawesi and North Sulawesi, and some even come from outside Sulawesi, such as Java and Maluku. 
Some of the communities even argue that cousin marriages sociologically and medically can have a negative impact in relation to brotherhood in case of conflict and the emergence of various congenital diseases. ${ }^{22}$

\subsection{Dampak Pernikahan Sepupu}

Cousin marriages that occur in the Mandar tribe community in Kalola Village have an impact on the family and society, both positively and negatively.

\section{Positive Impact}

a). Reducing the number of conflicts

According to the head of Kalola Village, every year there are almost no conflicts in Kalola Village, both internal and external conflicts. This has a correlation with cohesiveness and harmony in the social circle of the Kalola Village community, because of the strong kinship relationship, and this is one of the positive values for the government in particular and the village community in general. ${ }^{23}$

The harmony that occurs in the social life of the Kalola Village community illustrates the success of the community in implementing Islamic values, especially in family matters. Seeing the purpose of marriage is to create a sakinah, mawaddah, warahmah life. This is all reflected in the behavior of the majority of the people there. And based on the observation, the people of Kalola

${ }^{22}$ Yayuk Yusdiawati, "Penyakit Bawaan, Kajian Resiko Kesehatan Pada Perkawinan Sepupu," Jurnal Internasional 19, no. Sosial (2017): 89-99.

${ }^{23}$ Interview with Logawali, a Head of Village, 7 April 2020.
Village live in a fairly strong circle of harmony.

The explanation above shows that marriage is a way to strengthen the family. By getting married, humans can strengthen family relationships, strengthen, and even expand family networks.

b). Strengthening family political system

The next impact that emerged from the cousin's marriage in Kalola Village was the strong kinship political system. Solidarity and good cooperation between families gave birth to a good political system in the social system built by the people of Kalola Village. Every time a village head election takes place, it is always won by the person chosen from the results of family deliberations.

Every time a the election of village head will be held, almost all family heads are gathered to be asked for their views regarding who is suitable as a candidate for a village head. From there, the names that will be discussed and asked for to become candidates for village head emerge. However, it must meet several requirements. ${ }^{24}$

One example is Logawali, who now sits as a head of Kalola village, chosen from the results of the internal family deliberations. From here, the author can see that the cousin marriage that occurs in Kalola Village can have a big impact on the sustainability of the existing government system holders in in this area. 


\section{Negative impact}

As previously explained, cousin marriage is the most effective way to strengthen family relationships, because it is able to bring together two couples coming from their own families. However, cousin marriage can also lead to rifts in the family if problems occur, such as divorce, ${ }^{25}$ seizure of property, misunderstandings, and so on. A family that was united and strong will be fractured due to the separation of husband and wife, and it will take a very long time to unite the kinship of the two families.

From a fungsionalism-structural perspective, using Malinowsky theory, which emphasizes that every pattern of behavior, beliefs and attitudes, becomes part of the culture of a society and has a fundamental role in culture concerned, it can be said that cousin marriage is part of the cultural customs of the Kalola Village community which has a fundamental role in the social structure of society, starting from maintaining the integrity of the family, safeguarding family assets and establishing an ideal marriage. While the impact of cousin marriages is to reduce the number of social conflicts, the formation of kinship political systems and can also cause major conflicts within the family due to disunity.

In addition, from the objectives of Islamic law (maqasid al-shari'ah) ${ }^{26}$

${ }^{25}$ For the study of talaq from the Quranic perspective, see Rusli Rusli, "Hermeneutical Reading of Țalāq," HUNAFA: Jurnal Studia Islamika 12, no. 2 (2016): 209-229.

26 For more explanation on Maqasid alShariah from another perspective, see Rusli Rusli, perspective, that emphasizes on five fundamental principles, such as the protection of religion, soul, intellect, property, and offspring, it can be argued as follows:

a) Protection of religion (hifz al-din)

In general, religion means belief in God. In particular, religion means a set of faith, worship, and laws that are prescribed by Allah, which regulates the human relationship with God and also fellow humans. In marriage, the community of Kalola village cousins can be said to be able to maintain their respective religions, in this case if their family is Muslim, then their belief in their religion will be maintained.

b) Protection of soul (hifz al-nafs)

Marriage in Islam is one way to have children, and to protect offsprings and maintain their existence as a human being. In cousin marriages, maintaining the inheritance is deemed necessary to maintain the continuity of the offspring as a cultured society. Where maintaining the integrity of the family can also be maintained properly.

c) Protection of intellect (hifz al-'aql)

When viewed from the health aspect, cousin marriage can have a negative impact on a person's physical condition, such as hereditary disease, physical disabilities, weakness in thinking and so on. Besides that, cousin marriage also has a good social impact, as previously explained.

"Wahhabi Salafism's View on Maqasid AlSyariah," Al-Manahij: Jurnal Kajian Hukum Islam 8, no. 2 (2014): 167-180.

e-ISSN: 2715-4580 p-ISSN: 2715-8268 
d) Protection of property (hifz al-mal) Islam does not prohibit its people from seeking wealth and possessing abundant wealth, as long as these assets are obtained in a good way, and can be used to enrich good deeds for provision in the future. Islam also advises us to protect property from prohibition and obscurity.

In the practice of cousin marriage, safeguarding property is one of the impacts. The point is, the cousin marriage carried out by the Kalola Village community, will have an impact in the process of maintaining family property ownership, which is none other than family property. With cousin marriages, family assets will be maintained and managed by their own families.

\section{Conclusions}

From the explanation above, it can be concluded that the background of a cousin marriage in the Mandar tribe community in Kalola Village is a tradition that has been strong for a long time in the community, in addition to the factor of maintaining a large family and protecting property.

Meanwhile, the impact of cousin marriage includes both positive and negative impacts. The positive impact is to reduce the number of conflicts in the community and strengthen local political systems, while the negative impact is the breakdown of kinship in the event of conflict and divorce and health risks.

\section{REFERENCES}

Aulia, Nuansa, Kompilasi Hukum Islam, Cet II, Bandung; TIM Redaksi Nuansa Aulia, 2008.

Abubakar bin Muhammad Al-Husaini Ad-dimasyqi Asy-Syafi'I, Taqiyudin, Kifayatul Akhyar, Cet I ; Sukoharjo: Darul Aqidah, 2017.

Ahmad, Kadir, Sistem Pernikahan di Sulawesi Selatan dan Sulawesi Barat, Cet I ; Makassar : Indobis Publishing, 2016.

Afandi, Ali, Hukum Waris, Hukum Keluarga, dan Hukum Pembuktian Menurut Undang-Undang Hukum Perdata, Cet I, Jakarta: Bina Aksara, 1986

A Rahman, Bakri dan Ahmad Sukardja, Hukum Perkawinan Menurut Islam, UUP dan Hukum Perdata, Cet I, Jakarta: PT Hidakarya Agung, 1981

Basyir, Ahmad Azhar, Dalam Ahmad Kuzari, Nikah Sebagai Perikatan, Cet I, Jakarta: Raja Grafindo, 1995

B. Milles, Mattew dan Huberman, A. Michael, Qualitative Data Analysis, Diterjemahkan Oleh Tjecep Rohendi, Analisis Data Kualitativ, Buku Tentang Metode-metode Baru, Cet, I; Jakarta: UI Pers, 2005.

Badan Pengembangan dan Pembinaan Bahasa Kementrian Pendidikan dan Kebudayaan, Kamus Besar Bahasa Indonesia, Jakarta : Balai Pustaka, 2018.

Burhan, Ahmad, Jurnal Internasional, Tinjauan Hukum Islam Terhadap Larangan Perkawinan Dengan Sepupu Di Desa Sukaoneng Kecamatan Tambak Baweang Kabupaten Gresik, Diakses pada tanggal 18 Oktober 2019.

e-ISSN: 2715-4580 p-ISSN: 2715-8268 
International Journal of Contemporary Islamic Law and Society

Vol. 2 No. 2 Tahun 2020

Basiq, Djalil, Peradilan Agama Di Indonesia: Gemuruhnya Politik Hukum Hukum Islam, Hukum Barat dan Hukum Adat), Cet I, (Jakarta: Kencana, 2006

Darmadi, Hamid, Metode Penelitian, Cet I ; Bandung : Alvabeta CV Bandung, 2011.

Departemen Agama RI, Pedoman Pegawai Pencatat Nikah (PPN), Proyek Peningkatan Tenaga Keagamaan Dirjen Bimmas Islam dan Penyelenggaraan Haji, Jakarta : Departemen Agama RI, 2014.

Burhan, Ahmad, Jurnal Internasional, Tinjauan Hukum Islam dan Hukum Adat Terhadap Larangan Perkawinan Dengan Sepupu Di Desa Sukaoneng Kecamatan Tambak Baweang Kabupaten Gresik, Diakses pada tanggal 18 Oktober 2019.

Departemen Agama RI, Al-Qur'an dan Terjemahan, Cet. V ; JatinegaraJakarta: CD Darus Sunnah, 2002.

Djazuli, Kaidah-kaidah Fikih, Cet I ; Bandung : Tirtawening, 2006.

Gemala dewi Dkk. Hukum perikatan Islam Indonesia, Cet. I : Jakarta : Kencana, 2005.

Ghozali, Abdul Rahman, Fiqih Munakahat. Cet. I ; Jakarta: Kencana Prenada Media, 2010.

Hanbal, Abu Abdillah Ahmad, Musnad Ahmad Bin Hanbal, Juz III Disertai Catatan Pinggir Dari Ali Bin Hisam al-Din al-Muqti, Muntakhab Kunzil Ummah Fi Sunanil Aqwam Wa Af'al, Beirut : al-Maktabah alIslam, 1978.

Haryono, Anwar, Hukum Islam Keleluasaan dan Keadilan dalam
Keluarga, Cet II ; Jakarta : PT Midas Surya Grafindo, 1968.

Herdiansyah, Haris, Wawancara, Observasi dan Focus Grups: sebagai Instrumen Penggalian Data Kualitatif, Cei I ; Jakarta : Rajawali Pers, 2013.

Ihroni, T.O, Pokok-pokok Antropologi Budaya, Cet I ; Jakarta : Yayasan Obor Indonesia 1999.

Kaelan, Metodologi Penelitian Agama Kualitatif Interdisiplinar Cet I ; Yogyakarta: Paradigma, 2010.

Kamus Besar Bahasa Indonesia Pusat Bahasa, Edisi Keempat, Jakarta : Gramedia Pustaka Utama.

Khalllaf, Abdul Wahhab, Ilmu Ushul Fiqh, Cet. I ; Semarang : Dina Utama, 1994.

Kaelany H.D, Islam dan Aspek-aspek Sosial Kemasyrakatan, Cet I, Bandung: Bumi Aksara, 2015.

Mardani, Hukum Islam Dalam Hukum Positif Indonesia, Cet I, Depok: PT Raja Grafindo Persada, 2018.

Moleong, Lexy, Metodologi Penelitian Kualitatif, Cet I, Bandung: Remaja Rosda Karya, 2005.

Mu'allim, Muhammad Amir, "Adat Kebiasaan dan Kedudukannya Dalam Perkembangan Hukum Islam di Indonesia" Al-Mawardi Edisi IV, Desember 2001-Maret 2002.

Muslih, I., Nurdin, N., \& Marzuki, M. (2020). Effectiveness of Marriage Services Through Information System Management (SIMKAH) at Palu City Religious Court INTERNATIONAL JOURNAL OF CONTEMPORARY ISLAMIC LAW AND SOCIETY, 2(1), 20-36. 
Mubarok, Jaih, Qaidah Fiqh, Sejarah dan Kaidah Asasi, Cet. I : Jakarta : Rajawali Pers: 2007.

Mustari, Abdillah, Reinterpretasi Konsepkonsep Pernikahan Cet I ; Samata : Alauddin University, 2011.

Nenni Rachman, Perkawinan Endogami Perspektif Hukum Adat dan Hukum Islam (Studi Terhadap Masyarakat Bugis Bune), Diakses pada tanggal 18 Oktober 2019.

Nurdin, N. (2017a). Research in Online Space: The Use of Social Media for Research Setting Jurnal Sistem Informasi (Journal of Information System), 13(1), 67-77.

Nurdin, N. (2017b). To Research Online or Not to Research Online: Using Internet-Based Research in Islamic Studies Context. Indonesian Journal of Islam and Muslim Societies, 7(1), 31-54.

Nurdin, N., \& Yusuf, K. (2020). Knowledge management lifecycle in Islamic bank: the case of syariah banks in Indonesia. International Journal of Knowledge Management Studies, 11(1), 59-80. https://doi.org/10.1504/ijkms.20 20.105073

Prawirohamidjojo, Soetojo, dan Marthalena Pohan, Hukum Orang Dan Keluarga, Cet I, (Surabaya: Univercity Press, 2000.

Prawirohamidjojo, Soetojo, Pluralisme Dalam Perundang-undnagan Perkawinan Di Indonesia, Cet II, Surabaya: Airlangga Pres, 2002.

Rafiq, Ahmad, Hukum Adat Di Indonesia, Cet. III ; Jakarta : Raja Grafindo Persada, 2013.
Rafiq, Ahmad, Hukum Perdata Islam Di Indonesia, Cet. III ; Jakarta : Raja Grafindo Persada, 2013.

Rifai, Mohammad, Fiqh Islam Lengkap, (Cet I ; Semarang : PT Karya Toha Putera, 2014.

Robert Bohdan dan Steven J. Taylor, Pengantar Metode Penelitian Kualitatif Suatu Pendekatan Fenomenologi Terhadap Ilmu-ilmu Sosial. Cet I ; Surabaya : Usaha Ofset Printing 2015.

Rusli, Rusli. Nalar Fikih Tradisional Progresif: Analisis terhadap Epistemologi Ibrahim Hosen. $1^{\text {st }}$ edition. Yogyakarta: Maghza Books, 2014.

Rusli, Rusli. “Wahhabi Salafism's View on Maqasid al-Syariah." AlManahij: Jurnal Kajian Hukum Islam 8, no. 2 (2014): 167-180.

Rusli Rusli, "Hermeneutical Reading of TTalāq," HUNAFA: Jurnal Studia Islamika 12, no. 2 (2016): 209-229.

Rusli, Rusli. "The Role of Family in Preventing Social Conflict in Society from Islamic Perspective." Hunafa: Jurnal Studia Islamika 17, no 1 (2020): 108-122.

Rusyd, Ibnu, Bidayatul Mujtahid Wa Nihayatul Muqtashid, Jilid II, Cet I ; Jakarta Timur : Al-Mizan, 2016.

Rahman I. Doi, Abdul, Shariah The Isamic Law, Terjemahan, Basri Iba Asghary dan Wadi Masturi, Perkawinan dan Syariat Islam, Cet I, Jakarta: Rineka Cipta.

Rusli, R. (2018). Fikih Ekologi dan Kearifan Tradisional: Tinjauan Terhadap Konsep Ihya' al-Mawat dan Hima. Hunafa: Jurnal Studia Islamika, 5(3), 287-298.

e-ISSN: 2715-4580 p-ISSN: 2715-8268 
Rusli, Tami, Pembatalan Perkawinan Berdasarkan Undang-Undang Nomor 1 Tahun 1974 Tentang Perkawinan, Cet I, Lampung: Jurnal Pranata Hukum Vol. 8 No 2 Juli 2013.

Syahrani, Riduan, Masalah-masalah Hukum Adat Perkawinan Di Indonesia, Cet I, Jakarta: PT Media Sarana Press, 2015.

Syarifuddin, Amir, Hukum Perkawinan Di Indonesia, Cet I, Jakarta: Kencana 2006.

Saidong, Husain, Nilai-nilai Upacara Tradisional Massawe Saeang Puttu'du Makassar : Balai Kajian Sejarah dan Nilai Tradisional Makassar, 2001, 13.

Saifuddin, Achmad, Antropologi Kontemporer: Suatu Pengantar Kritis Mengenai Paradigma, Cet I ; Jakarta : Prenada Media 2005.

Saifuddin, Lukman Hakim, Moderasi Beragama, Cet. I ; Jakarta : Kementrian Agama RI, 2019.

Sanusi, Ahmad, Ushul Figh Cet.I ; Jakart : PT Raja Grafindo Persada, 201598.

Satria Effendi, Problematika Hukum Keluarga Islam Kontemporer, (Cet III ; Jakarta : Kencana Prenada Media Grub, 2010.

Shidiq, Sapiudin, Ushul Figh, (Cet I ; Jakarta : Kharisma Putera Utama, 2011, 99.

Sudarsono, Pokok-Pokok Hukum Islam, Cet I ; Jakarta : Rineka Cipta, 1992602.

Soekarno, Meninjau Hukum Adat Di Indonesia: Suatu Pengantar Untuk Mempelajari Hukum Adat, Cet I, Jakarta: Raja Grafindo Persaja, 2002.
Sugiono, Metode Penelitian Pendidikan, Pendekatan Kualitatif, Kuantitatif, dan RED, Cet 11 ; Bandung : Alfabeta CV, 2015.

Sukardi, Metodologi Penelitian Pendidikan, Kompetensi dan Praktinya, Cet I ; Jakarta : PT Bumi Aksara, 2008.

Syeikh al-allamah Muhammad bin Abdurrahman al-dimasyqi, Fiqih Empat Madzhab, Cet 18 ; Bandung : PT Hasyimi, 2017.

Subekti, Pokok-pokok Hukum Perdata, Cet I, Jakarta: Inrtemasa, 2000.

Soehadha, Moh ,Jurnal Studi Agama, Teori Fungsional B. Malinowski Implikasi Terhadap Studi Agama-Agama, UIN Sunan Kalijaga Vol. IV, No. 1, Januari 2005.

Salim, H.S, Pengantar Hukum Perdata Tertulis (BW), Cet I, Jakarta: Sinar Grafika, 2002.

Tutik, Titik Triwulan, Hukum Perdata Dalam Sistem Hukum Nasional, Cet V, Jakarta: Kencana, 2015.

W. Al-Hafiz, Ahsin, Kamus Figh Cet I ; Jakarta : Amzah, 2013.

Wahhab Khallaff, Abdul, Ushul Fiqhi Kaidah Hukum Islam, Ahli Bahasa Faiz El Muttaqin Jakarta : Pustaka Amani, 2002.

Yayuk Yusdiawati, Jurnal Internasional, Penyakit Bawaan, Kajian Resiko Kesehatan Pada Perkawinan Sepupu, 2017, Diakses pada tanggal 18 Oktober 2019.

Ema Rahmaniah, Syarifah" "Multikulturalisme Dan Hegemoni Politik Pernikahan Endogami: Implikasi Dalam Dakwah Islam," Walisongo Volume 22, Nomor 2, November 2014. 